https://doi.org/10.15407/ujpe64.3.245

S.I. YUSHCHUK, S.O. YURYEV, N.T. POKLADOK

National University "Lviv Polytechnic"

(12, S. Bandera Str., Lviv 79013, Ukraine; e-mail: s.o.yuryev@gmail.com)

\title{
GROWING OF THICK SINGLE-CRYSTALLINE La-SUBSTITUTED YTTRIUM-IRON GARNET FILMS WITH REPRODUCIBLE PARAMETERS
}

\begin{abstract}
Basic principles of growing the thick $(35-60 \mu \mathrm{m})$ single-crystalline La-substituted yttriumiron garnet $\left(Y_{3-x} L a_{x} F_{5} O_{12}\right.$, La: YIG) films with reproducible parameters have been formulated. La: YIG films are grown on gallium-gadolinium garnet $\left(\mathrm{Gd}_{3} \mathrm{Ga}_{5} \mathrm{O}_{12}\right)$ substrates from a supercooled melt-solution (MS) consisting of $\mathrm{Y}_{2} \mathrm{O}_{3}, \mathrm{La}_{2} \mathrm{O}_{3}$, and $\mathrm{Fe}_{2} \mathrm{O}_{3}$ oxides and the $\mathrm{PbO}$ $\mathrm{B}_{2} \mathrm{O}_{3}$ solvent. In order to minimize the implantation of $\mathrm{Pb}^{2+}$ ions into the films, which degrades the film quality, the epitaxy has to be performed at high temperatures and a low MS supercooling. It is found that, in order to maintain a constant growth rate of La: YIG films with reproducible parameters, a large MS mass (10-16 kg) has to be used, and the MS temperature has to be permanently lowered at a rate of $0.042 \mathrm{~K} / \mathrm{min}$.
\end{abstract}

Ke ywords: single-crystalline yttrium-iron garnet films, liquid-phase epitaxy, ferromagnetic resonance.

\section{Introduction}

Single-crystalline films of yttrium-iron garnet $\mathrm{Y}_{3} \mathrm{Fe}_{5} \mathrm{O}_{12}$ (YIG) are a promising material for the microminiaturization of solid-state ultrahigh-frequency (UHF) devices [1]. Two main requirements are demanded from UHF devices operating on magnetostatic waves (MSWs): minimum magnetic losses at the MSW propagation and a high frequency stability in the working temperature interval. Magnetic losses depend on the line width $\Delta H$ of a ferromagnetic resonance (FMR): the narrower the FMR line, the lower are the magnetic losses. The working frequency is determined by such parameters as the saturation magnetization and the magnetic anisotropy field. Of great practical importance is the power increase of UHF devices based on single-crystalline YIG films. In this connection, there arises a problem of producing thick, up to $100 \mu \mathrm{m}$ in thickness, single-

(c) S.I. YUSHCHUK, S.O. YURYEV, N.T. POKLADOK, 2019 crystalline films, which would possess the properties of bulk single crystals, for which the parameter $\Delta H=0.2 \div 0.5$ Oe.

The YIG films are grown with the use of the liquid-phase epitaxy (LPE) method on substrates made of single-crystalline gadolinium-gallium garnet $\mathrm{Gd}_{3} \mathrm{Ga}_{5} \mathrm{O}_{12}$ (GGG). The latter are obtained with the help of Czochralski method. Owing to a mismatch between the crystal lattice parameters in YIG $\left(a_{f}=\right.$ $=12.376 \AA)$ and GGG $\left(a_{f}=12.383 \AA\right)$, as well as between the corresponding heat expansion coefficients, thick YIG films have not been managed to grow, because, when reaching a thickness of $15-20 \mu \mathrm{m}$ and being subjected to high mechanical stresses, those films cracked. At first glance, this problem seemed to be solvable by modifying the technology of film growing.

To lower the melting point of a ferrite charge, fluxing agents containing lead oxide $(\mathrm{PbO})$ are added to the latter. Lead ions $\mathrm{Pb}^{2+}$ are characterized by a larger ion radius than yttrium ones: $R\left(\mathrm{~Pb}^{2+}\right)=$ $=1.29 \AA$ versus $R\left(\mathrm{Y}^{3+}\right)=1.015 \AA$. Therefore, the 
former tend to replace the latter at dodecahedral positions in the garnet when growing a ferrite film. The presence of lead ions in the YIG lattice increases its parameter.

The implantation of lead into the YIG film seemed to be controllable by governing the film growth temperature $T_{\mathrm{p}}$. Following this way, $\mathrm{Pb}: \mathrm{YIG}$ films $110 \mu \mathrm{m}$ in thickness were managed to grow [2]. However, the quality of such films was much worse than the quality of films about $10 \mu \mathrm{m}$ in thickness. This fact is explained by the impossibility of a precise control over the implantation of $\mathrm{Pb}^{2+}$ ions into the film, because the implantation degree is extremely sensitive to changes in temperature regimes and, therefore, becomes almost uncontrollable. The negative influence of $\mathrm{Pb}^{2+}$ ions on the parameter $\Delta H$ was noted in works [3-5].

The aim of this work is to study the possibility of growing the thick YIG films with homogeneous physical properties over their area and characterized by a narrow FMR line. To this end, the lattice parameter of a ferrogarnet film $a_{f}$ was increased to the value of the substrate lattice parameter $a_{s}$ by partially substituting $\mathrm{La}^{3+}$ ions for $\mathrm{Y}^{3+}$ ones. The former are characterized by a larger ionic radius, $R\left(\mathrm{La}^{3+}\right)=1.22 \AA$, and are nonmagnetic, so that they do not affect magnetic losses.

In order to determine the initial MS phase, the socalled Blanc-Nielsen coefficients are introduced [5], which are the molar ratios between the MS components:

$$
\begin{aligned}
R_{1} & =\frac{\mathrm{Fe}_{2} \mathrm{O}_{3}}{\mathrm{Y}_{2} \mathrm{O}_{3}+\mathrm{La}_{2} \mathrm{O}_{3}} ; \\
R_{2} & =\frac{\mathrm{La}_{2} \mathrm{O}_{3}}{\mathrm{Y}_{2} \mathrm{O}_{3}} ; \quad R_{3}=\frac{\mathrm{PbO}}{\mathrm{B}_{2} \mathrm{O}_{3}} ; \\
R_{4} & =\frac{\mathrm{Fe}_{2} \mathrm{O}_{3}+\mathrm{Y}_{2} \mathrm{O}_{3}+\mathrm{La}_{2} \mathrm{O}_{3}}{\Sigma_{\text {oxides }}} .
\end{aligned}
$$

The coefficient $R_{1}$ characterizes the limits of the garnet crystallization interval and determines the MS homogeneity. The coefficient $R_{4}$ characterizes the content of garnet forming components and determines the melt saturation temperature $T_{\mathrm{n}}$. With decreasing the coefficient $R_{3}$, the MS viscosity increases, whereas an increase in $R_{3}$ corresponds to a reduction of the YIG field compositional stability and a growth of the solvent volatility. Finally, the coefficient $R_{2}$ is deter- mined on the basis of the required concentration of substituting ions (e.g., $\mathrm{La}^{3+}$ ) in the ferrite film.

\section{Experimental Part}

Epitaxial $\mathrm{Y}_{3-x} \mathrm{La}_{x} \mathrm{Fe}_{5} \mathrm{O}_{12}$ (La: YIG) films were grown, by using the method of liquid phase epitaxy on GGG substrates with the (111) orientation. For this purpose, the supercooled MS consisting of the garnet forming oxides $\mathrm{Y}_{2} \mathrm{O}_{3}, \mathrm{La}_{2} \mathrm{O}_{3}$, and $\mathrm{Fe}_{2} \mathrm{O}_{3}$ and the $\mathrm{PbO}-\mathrm{B}_{2} \mathrm{O}_{3}$ solvent with a total mass of $12 \mathrm{~kg}$ was used. The supercooling degree $\Delta T$ of the meltsolution was determined as the difference between the saturation, $T_{\mathrm{n}}$, and growth, $T_{\mathrm{p}}$, temperatures: $\Delta T=T_{\mathrm{n}}-T_{\mathrm{p}}$. The GGG substrates had a thickness of $0.5 \mathrm{~mm}$ and a diameter of $76.2 \mathrm{~mm}$. The substrates were subjected to the chemical-mechanical polishing to the 14th purity grade. For the epitaxial growing, an automated installation was used, i.e., technological operations were controlled by a computer. The temperature in the furnace was maintained with an accuracy of $\pm 0.1 \mathrm{~K}$.

The FMR line width in La: YIG films was measured, by using a non-destructive method in a frequency interval of $1.2-4.0 \mathrm{GHz}$ [6]. The saturation magnetization of the films was monitored with the help of a vibration magnetometer [7]. The structure and composition of epitaxial films were studied, by using a scanning electron microscope equipped with a Comebax X-ray microanalyzer.

\section{Research of Lead and Lanthanum Ion Implantation Into a Ferrogarnet Film}

In our previous studies [8], the lattice parameter of a La:YIG film was revealed to linearly increase with the lanthanum ion content. On the basis of corresponding calculations, it was found that if the lanthanum concentration is about $0.04-0.06$ atoms per formula unit, the lattice parameter of the La: YIG film reaches a value typical of the lattice parameter in the substrate with GGG.

Ferrogarnet films were grown from more than 10 different charge compositions. The most optimal among them corresponded to the following component ratios (in mol\%) and molar coefficients:

$$
\begin{aligned}
& \mathrm{PbO}-79.99 ; \quad \mathrm{B}_{2} \mathrm{O}_{3}-5.13 ; \quad \mathrm{Fe}_{2} \mathrm{O}_{3}-14.40 \\
& \mathrm{Y}_{2} \mathrm{O}_{3}-0.43 ; \quad \mathrm{La}_{2} \mathrm{O}_{3}-0.05 ; \\
& R_{1}=30 ; R_{2}=0.116 ; R_{3}=15.6 ; R_{4}=0.149 \\
& T_{\mathrm{n}}=1233 \mathrm{~K} .
\end{aligned}
$$

$$
\text { ISSN 2071-0194. Ukr. J. Phys. 2019. Vol. 64, No. } 3
$$


This charge composition was used to produce films with a chemical composition corresponding to the formula $\mathrm{Y}_{2.958} \mathrm{La}_{0.042} \mathrm{Fe}_{5} \mathrm{O}_{12}$.

As was mentioned above, the lattice parameter of an YIG film can also grow, if $\mathrm{Pb}^{2+}$ ions are implanted into the film, which is extremely undesirable because thick $\mathrm{Pb}$ : YIG films have magnetic properties that are inhomogeneous over the film surface, a low surface quality, and high magnetic losses. Therefore, the aim of our study was to determine such growth conditions, at which the implantation of lanthanum ions rather than lead ones into the crystalline structure of an YIG film would increase its lattice parameter.

Figure illustrates the contents of $\mathrm{La}^{3+}$ and $\mathrm{Pb}^{2+}$ ions in the La: YIG films as functions of the MS supercooling temperature. It is evident that the ion contents $X_{\mathrm{La}}$ and $X_{\mathrm{Pb}}$ per formula unit increase with $\Delta T$, this growth being more pronounced for $\mathrm{La}^{3+}$ ions. Furthermore, it was found that, provided the same MS supercooling, the implantation of $\mathrm{La}^{3+}$ ions occurs more intensively with the temperature growth in comparison with $\mathrm{Pb}^{2+}$ ones. Therefore, in order to reduce the lead concentration in La: YIG films, the latter should be grown at higher temperatures and at a low supercooling.

Using a formula proposed in work [2] for estimating the lattice parameter of YIG films with dodecahedral substitution $\left\{\mathrm{Y}_{3-x} R_{x}\right\}\left[\mathrm{Fe}_{2}\right]\left(\mathrm{Fe}_{3}\right) \mathrm{O}_{12}$, we can estimate the contribution of $\mathrm{La}^{3+}$ ions to the $\mathrm{La}$ : YIG lattice parameter value and compare it with a contributions of $\mathrm{Pb}^{2+}$ ions:

$a_{x}=12.376 \AA+\frac{x}{3} \times 2.23\left(r_{R}-1.015 \AA\right)$,

where the first term is the lattice parameter of pure YIG, $1.015 \AA$ is the radius of dodecahedral $\mathrm{Y}^{3+}$ ions, and $r_{R}$ the radius of substituting element $R: r\left(\mathrm{~Pb}^{2+}\right)$ or $r\left(\mathrm{La}^{3+}\right)$.

From Figure, we obtain that, at $\Delta T=20 \mathrm{~K}$, the contents $X_{\mathrm{Pb}}=0.012$ and $X_{\mathrm{La}}=0.038$. Then, from Eq. (3), we determine the variation of the lattice parameter

$\Delta a_{x}=\frac{x}{3} \times 2.23\left(r_{R}-1.015 \AA\right)$,

which can be induced by lanthanum and lead ions at the MS supercooling $\Delta T=20 \mathrm{~K}$. As a result, the growth of the lattice parameter caused by the implantation of $\mathrm{La}^{3+}$ ions equals $\Delta a_{x}(\mathrm{La})=0.0059 \AA$,

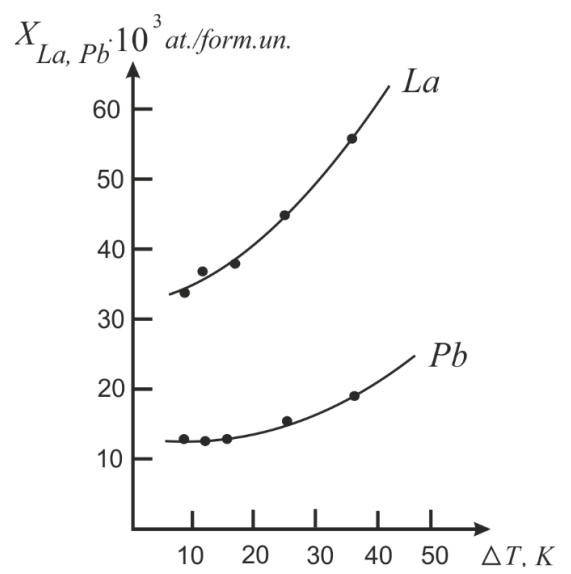

Dependences of the $\mathrm{La}^{3}+$ and $\mathrm{Pb}^{2}+$ ion contents $\left(X_{\mathrm{La}, \mathrm{Pb}}\right)$ in La : YIG films on the supercooling temperature $\Delta T$

which is more than twice as large as the increase induced by the implantation of $\mathrm{Pb}^{2+}$ ions, $\Delta a_{x}(\mathrm{~Pb})=$ $=0.0024 \AA$. At $\Delta T=30 \mathrm{~K}$ (see Figure), we obtain that $\Delta a_{x}(\mathrm{La})=0.0087$ and $\Delta a_{x}(\mathrm{~Pb})=0.0037 \AA$.

At high growth temperatures (small supercooling), the implantation of lead ions from the meltsolution into the ferrite film is minimum. Therefore, the chemical composition of the film is mainly determined by the initial charge composition. This circumstance makes the growth process more technological due to a high reproducibility of results, 40-50\%.

\section{Fabrication of Ferrogarnet Films with Reproducible Parameters}

When choosing a regime of thick film growing using the LPE method, the MS depletion should be taken into consideration. It occurs due to the following factors: 1) lead evaporation during the growth and MS homogenization, 2) melt depletion with respect to garnet-forming components during the film growth, and 3) a reduction of the melt amount because of the formation of droplets and accretions on the ferrite epitaxial structure (FES) and the equipment. When fabricating a single FES with ferrite coating from two sides, the garnet mass taken from the melt can be determined by the formula

$G=2 \pi \rho h R^{2}$

where $R$ is the substrate radius, $h$ the film thickness, and $\rho=5.17 \times 10^{3} \mathrm{~kg} / \mathrm{m}^{3}$ is the garnet density. The 
Growth regimes

and physical parameters of La : YIG films

\begin{tabular}{|c|c|c|c|c|c|}
\hline $\begin{array}{c}\text { Speci- } \\
\text { men } \\
\text { No. }\end{array}$ & $\begin{array}{c}\text { Growth } \\
\text { tempe- } \\
\text { rature, K }\end{array}$ & $\begin{array}{c}\text { Growth } \\
\text { rate, } \\
\mu \mathrm{m} / \mathrm{min}\end{array}$ & $\begin{array}{c}\text { Super- } \\
\text { cooling } \\
\text { degree, K }\end{array}$ & $\begin{array}{c}\text { Film } \\
\text { thickness, } \\
\mu \mathrm{m}\end{array}$ & $\begin{array}{c}\text { FMR line } \\
\text { width, } \AA\end{array}$ \\
\hline 1 & 1122 & 0.53 & 11 & 27.9 & 0.56 \\
2 & 1213 & 0.57 & 20 & 34.7 & 0.56 \\
3 & 1213 & 0.56 & 20 & 34.4 & 0.47 \\
4 & 1216 & 0.56 & 17 & 50.9 & 0.55 \\
5 & 1209 & 0.61 & 24 & 62.3 & 0.71 \\
\hline
\end{tabular}

corresponding mass losses of garnet-forming oxides equal

$$
\begin{aligned}
& A\left(\mathrm{Y}_{2} \mathrm{O}_{3}\right)=\frac{G 45.13}{100} ; \quad B\left(\mathrm{Fe}_{2} \mathrm{O}_{3}\right)=\frac{G 53.95}{100} ; \\
& C\left(\mathrm{La}_{2} \mathrm{O}_{3}\right)=\frac{G 0.93}{100},
\end{aligned}
$$

where the numerators mean the mass percentages of yttrium, iron, and lanthanum oxides in 1 mole of the $\mathrm{Y}_{2.958} \mathrm{La}_{0.042} \mathrm{Fe}_{5} \mathrm{O}_{12}$ ferrite grown from charge (2). By recalculating oxide losses (5) into molar percentages, the changes of the coefficients $R_{1}$ and $R_{4}$ can be determined.

Our research showed that if the coefficient $R_{1}$ increases by one, the saturation temperature of the melt $T_{\mathrm{n}}$ decreases by $3 \mathrm{~K}$, whereas an increase of the coefficient $R_{4}$ by one leads to a decrease of $T_{\mathrm{n}}$ by $21.7 \mathrm{~K}$. Therefore, in order to obtain thick La: YIG films with reproducible parameters, it is necessary to use large melt masses $(10-16 \mathrm{~kg})$ and vary the growth temperature according to a definite law.

On the basis of calculations, we found that, in order to maintain a constant growth rate and obtain films with reproducible parameters, it is necessary to lower the growth temperature $T_{\mathrm{p}}$ by $3.79 \mathrm{~K}$ after every layer $50 \mu \mathrm{m}$ in thickness has been grown. As to the lead oxide losses through the evaporation, according to literature data [2] and the results of our researches, their contribution to a change of $T_{\mathrm{n}}$ is insignificant and can be neglected.

The melt-solution $10 \mathrm{~kg}$ in mass can retain its properties, when being supercooled by $25-30 \mathrm{~K}$. This mass allows $n=25 \mathrm{~K} / 3.79 \mathrm{~K} \approx 6 \mathrm{La}$ : YIG films, each $50 \mu \mathrm{m}$ in thickness and with almost identical parameters, to be grown without adding garnet-forming oxides and $\mathrm{PbO}$ to the crucible. If the growth rate of La: YIG films is $f_{\mathrm{p}}=0.56 \mu \mathrm{m} / \mathrm{min}$, then the growth time of one film equals $t_{\mathrm{p}}=50 \mu \mathrm{m} /(0.56 \mu \mathrm{m} / \mathrm{min})=$ $=89.3 \mathrm{~min}$. In this case, the rate of permanent reduction of the melt temperature at the batch growth of the films should be equal to

$$
\frac{\Delta T_{\mathrm{p}}}{t_{\mathrm{p}}}=\frac{3.79 \mathrm{~K}}{89.3 \mathrm{~min}}=0.042 \mathrm{~K} / \mathrm{min} \text {. }
$$

Thus, to fabricate thick La: YIG films with reproducible properties with the use of the LPE method, they should be grown, by taking a large mass of MS with a controllable content of garnet-forming oxides. In such a way, a change of the saturation temperature after the growing of each film can be minimized, and the growth rate can be maintained constant for each film in a batch during the whole growing session.

Finally, we would like to emphasize that the obtained thick La: YIG films possessed a mirror surface with no visible defects.

Table contains some technological and physical parameters for some La: YIG films grown from the melt of ferrite charge (2).

\section{Conclusions}

To minimize a variation of the melt-solution saturation temperature and thereby to provide the reproducibility of properties in a batch of thick La: YIG films grown by applying the LPE method, the MS with a large mass (10-16 kg) and a controlled content of garnet-forming oxide have to be used.

To reduce the lead concentration in La: YIG films, the latter have to be grown at high temperatures and with a low supercooling degree.

To maintain the constant rate of growth of thick La: YIG films within the whole growth session, the melt-solution temperature has to be permanently lowered at a rate of $0.042 \mathrm{~K} / \mathrm{min}$.

1. L.V. Lutsev, A.M. Korovin, V.E. Bursian, S.V. Gastev, V.V. Fedorov, S.M. Suturin, N.S. Sokolov. Low-relaxation spin waves in laser-molecular-beam epitaxy grown nanosized yttrium iron garnet films. Appl. Phys. Lett. 108, 182402 (2016).

2. H.L. Glass. Growth of thick single-crystal layers of yttrium iron garnet by liquid phase epitaxy. J. Cryst. Growth 33, 183 (1976).

3. M. Shone. The technology of YIG film growth. Circ. Syst. Sign. Proc. 4, 89 (1985).

ISSN 2071-0194. Ukr. J. Phys. 2019. Vol. 64, No. 3 
4. S.I. Yushchuk. The influence of lead and platinum impurity ions on the width of the ferromagnetic resonance linewidth of epitaxial iron-yttrium garnet films. Ukr. Fiz. Zh. 44, 1099 (1999) (in Ukrainian).

5. A.M. Balbashov, A.Ya. Chervonenkis. Magnetic Materials for Magnetoelectronics (Energiya, 1979) (in Russian).

6. S.I. Yushchuk, S.A. Yur'ev, P.S. Kostyuk, V.I. Nikolaychuk. A proximate and nondestructive quality control of epitaxial ferrogarnet films. Instrum. Exp. Tech. 54, 712 (2011).

7. S.I. Yushchuk, S.O. Yuryev, S.R. Zachek, V.V. Moklyak. Diagnostics of ferrogarnet films magnetization. Fiz. Khim. Tverd. Tila 15, 643 (2014) (in Ukrainian).

8. S.I. Yushchuk, S.O. Yuryev, P. S. Kostyuk, B.T. Semen. Investigation of growth rate effect on the quality of thick epitaxial yttrium-iron garnet films. In Abstracts of the 12th All-Union school-seminar "New magnetic materials of microelectronics" (Novgorod, 1990), p. 10 (in Russian).

Received 07.08.18.

Translated from Ukrainian by O.I. Voitenko
C.I. Ющук, C.O. Юр'єє, Н.Т. Покладок

ВИРОЩУВАННЯ ТОВСТИХ

МОНОКРИСТАЛІЧНИХ ПЛІВОК

Lа-ЗАМІЩЕНОГО ЗАЛІЗО-ІТРІЕВОГО ГРАНАТУ

З ВІДНОВЛЮВАЛЬНИМИ ПАРАМЕТРАМИ

$\mathrm{P}$ е $з$ ю м е

Сформульовано основні принципи вирощування товстих (35-60 мкм) монокристалічних плівок La-заміщеного залізо-ітрієвого гранату $\mathrm{Y}_{3-x} \mathrm{La}_{x} \mathrm{Fe}_{5} \mathrm{O}_{12}$ (La:ЗІГ) 3 відновлювальними параметрами при їх виготовленні. Плівки $\mathrm{La}:$ ЗІГ вирощували з переохолодженого розчину-розплаву (PP) оксидів $\mathrm{Y}_{2} \mathrm{O}_{3}, \mathrm{La}_{2} \mathrm{O}_{3}, \mathrm{Fe}_{2} \mathrm{O}_{3}$ і розчинника $\mathrm{PbO}-\mathrm{B}_{2} \mathrm{O}_{3}$ на підкладках 3 галій-гадолінієвого гранату $\mathrm{Gd}_{3} \mathrm{Ga}_{5} \mathrm{O}_{12}$. Для того, щоб звести до мінімуму впровадження в плівки іонів $\mathrm{Pb}^{2+}$, які погіршують їх якість, епітаксію слід проводити при високих температурах і малих переохолодженнях РР. Установлено, що для збереження сталої швидкості росту і отримання плівок La: ЗІГ з відновлювальними параметрами необхідно використовувати РP великої маси (10-16 кг) і неперервно знижувати температуру розплаву 3 швидкістю $0,042 \mathrm{~K} / \mathrm{xв}$. 